\title{
The Implementation of SAVI (Somatic, Auditory, Visual, and Intellectual) Learning Model toward Critical Thinking Ability of Students in Grade XI on the Subjects of Solubility and Solubility Product Constant (Ksp)
}

\section{*Sarmilah, Afadil \& Vanny M. A. Tiwow}

Chemistry Education / FKIP - Tadulako University, Palu - Indonesia 94119

Received 15 December 2020, Revised 18 January 2021, Accepted 17 February 2021

doi: $10.22487 / j 24775185.2021 . v 10.11 . p p 42-48$

\begin{abstract}
This study aimed to determine students' critical thinking ability through the implementation of SAVI (somatic, auditory, visual, and intellectual) learning model on the subject of solubility and solubility product constant (Ksp) at SMA Negeri 5 Model Palu. The study used one group pretest-posttest design. The instruments were lesson plans, critical thinking tests, students' worksheets, and validated observation sheets. Data of critical thinking abilities were analyzed using rubrics with three indicators, ie interpretation, analysis, and inference. Results of data analysis on students' critical thinking skills at the pretest on indicators of interpretation, analysis, and inference in Experiment class I were $25.84 \%, 11.13 \%$, and $2.44 \%$, respectively; while in Experiment class II were $23.51 \%$, $1.38 \%$, and $0 \%$, respectively. Critical thinking skills at the posttest of interpretation, analysis, and inference indicators in Experiment class I were 69.94\%, 61.13\%, and 53.51\%, respectively, while in Experiment class II were $79.55 \%, 48.61 \%$, and $49.07 \%$, respectively. The average of students' critical thinking skills ability in experiment class I was $61.02 \%$, and in experiment class II is $61.47 \%$. Both of them were in the moderate critical thinking category. This study concludes that students' critical thinking skills ability with the implementation of SAVI learning model is in a good category. The average of students' critical thinking skills ability in experiment class I was $61.02 \%$, and in experiment class $I I$ is $61.47 \%$. Both of them were in the moderate critical thinking category. This study concludes that students' critical thinking skills ability with the implementation of SAVI learning model is in a good category. The average of students' critical thinking skills ability in experiment class I was $61.02 \%$, and in experiment class II is $61.47 \%$. Both of them were in the moderate critical thinking category. This study concludes that students' critical thinking skills ability with the implementation of SAVI learning model is in a good category.
\end{abstract}

Keywords: SAVI, critical thinking, solubility, solubility product constant (Ksp).

\section{Introduction}

Chemistry learning can be carried out by learning that emphasizes students to be able to involve all the senses in order to be actively involved in learning. Chemistry is a subject that is generally abstract, so learning will be more effective if it involves all the senses in learning, this is in line with the results of research by Winarno (2009), which revealed that humans could absorb as much as $70 \%$ of what is done, $50 \%$ of what is done what they hear and see (audio-visual), whereas only $30 \%$ of what they see, only $20 \%$ of what is heard, and only $10 \%$ of what is read so that learning is more effective if it involves all senses in learning.

Other than that, one learning model that involves the whole body and all senses to learn is the SAVI (somatic, auditory, visual, intellectual) learning model. Somatic learning trains students to evaluate knowledge based on evidence. Auditory learning trains students to question, argue, and evaluate knowledge based on a collection of information obtained during auditory learning. Visual learning trains students to evaluate knowledge based on evidence. Finally, intellectual learning trains students to evaluate evidence, make generalizations, make decisions and solve problems (Handhika \& Rofiah, 2012; Fitriyani, 2015).

The SAVI learning model is a learning model that emphasizes students to be active by utilizing the senses as much as possible and making the whole body and mind involved in the learning process. Learning models are far more effective than those based on achievement, materials, and media because physical movement enhances mental processes. The SAVI learning model can be described in more detail, namely somatic is learning

*Correspondence

Sarmilah

e-mail: sarmilahmhyla@gmail.com

(c) 2021 the Author(s) retain the copyright of this article. This article is published under the terms of the Creative Commons Attribution License 4.0, which permits unrestricted non-commercial use, distribution, and reproduction in any medium, provided the original work is properly cited. 
with the sense of touch, kinesthetic, practical, involves physically, and uses and moves the body when learning. Auditory is the standard way of learning for all societies since the beginning of history. For example, encouraging people to learn aloud through dialogue. The auditory mind is more powerful than we realize, which when making one's voice by speaking, several important areas in our brain become active (Sumawardani, 2013; Azizah, 2016). Visual is learning by relying on sight. Students will learn more quickly if they can "see" what the teacher is teaching. Understanding this model will be better if the visualization is a tangible object that is concrete and can be observed. Intellectual is learning by using intelligence (mind) to reflect, create, solve problems, and build meaning (Suyadi, 2013).

Based on the characteristics of the SAVI learning model, it is hoped that it can support the achievement of a combination of competencies of knowledge, skills, and attitudes that are reflected in the habits of acting and thinking (Wiyani, 2012). The ability to think that can be developed is the ability to think critically, and this is because there is chemistry subject matter that is difficult to understand.

One of the problematic chemical topics is solubility and solubility product (Ksp). The chemical competence of solubility and the product of solubility is difficult to understand because students' understanding is limited to memorizing concepts and directly applying the concepts learned so that it is hoped that their creativity will also develop (Setiyono, 2011). Another difficulty that students usually experience is the solubility material, and the product of solubility is the inaccuracy of ionizing electrolytes so that if the student is wrong to ionize, the writing of the Ksp equation and the calculation of the Ksp price is also wrong (Rachman, 2017). This Ksp material will learn about the concept of solubility, the solubility product constant, and the influence of the namesake ion. This material is material that is not sufficient only by memorizing but also requires analytical skills because this material is related to several other materials such as the concept of moles and acids and bases so that students are required to think critically.

Critical thinking is reasoning in assessing something. Before making a decision or taking action, it is necessary to collect as much information as possible about that something. Basically, the ability to think critically is closely related to the critical thinking process and its indicators. Critical thinking indicators can be seen from their characteristics so that by having these characteristics, a person can be said to have the ability to think critically (Karim, 2015; Nurkholifah et al., 2018).

But in fact, the learning process applied by teachers is not a few who still use conventional learning in the learning process, while conventional learning does not support students' critical thinking skills for teacher-centered learning and teachers tend to use the lecture method in delivering material so that it is only suitable for students who have an auditory learning style that can easily understand the material just by listening to the explanation from the teacher. In contrast to students who have learned somatic, visual, and intellectual styles, they will find it difficult to face teaching and to learn in the lecture method; besides, students will feel tired and bored when learning takes place passively, this also affects their low critical thinking skills (Iskandar, 2016).

The low achievement of students' critical thinking skills indicates a gap between expectations of the world of education and the facts that occur in the field. The low critical thinking skills of students are caused by several factors that affect the learning process, including teacher, student, and other supporting factors for the implementation of learning (Susilowati, 2018).

Critical thinking indicators analyzed in this study are interpretation, analysis, and inference because students who think critically will be able to identify a problem, analyze various information related to the problem at hand, and draw the right conclusions for solving the problem (Lastyono, 2012).

This paper is intended to describe the application of the SAVI (somatic, auditory, visual, intellectual) learning model to the critical thinking skills of class XI students on the subject of solubility and solubility product (Ksp) in SMA Negeri 5 Model Palu.

\section{Methods}

This research was conducted at SMA Negeri 5 Model Palu, in class XI MIPA with 32 students in the experimental class 1 (XI MIPA 2) and 27 students in the experimental class 2 (XI MIPA 5). The sampling technique used was purposive sampling, namely, the technique of determining the sample by knowing the special characteristics that were adjusted to the results of the study; in this case, the consideration of the students' mean scores was almost the same.

The design used in this study was a onegroup pretest-posttest design which can be seen in Table 1 (Sukmadinata, 2012). 
Table 1. One group pretest posttest research design

\begin{tabular}{cccc}
\hline Class & Pretest & Treatment & Postest \\
\hline Experiment & $\mathrm{O} 1$ & $\mathrm{X}$ & $\mathrm{O} 2$ \\
\hline
\end{tabular}

where $\mathrm{O} 1$ is the Initial test; $\mathrm{X}$ is the Application of learning using the SAVI model; $\mathrm{O} 2$ is the Final test.

The use of the SAVI model in this study aims to describe the level of students' critical thinking skills. The level of critical thinking skills is measured based on critical thinking indicators adapted from Facione (2013), wherein in this study, three indicators are used.

\section{Interpretation}

Interpreting is understanding and expressing the meaning or significance of various experiences, situations, data, events, judgments, habits, or customs, beliefs, rules, procedures, or criteria.

\section{Analysis}

The analysis is identifying the intended and actual inferential relationships between statements, questions, concepts, descriptions, or other forms of representation intended to express beliefs, judgments, experiences, reasons, information, or opinions.

\section{Inference}

Inference means identifying and obtaining the elements necessary to make reasonable conclusions, making assumptions and hypotheses, considering relevant information, and inferring consequences from data and other forms of representation.

Students 'critical thinking skills are classified as good if at least the students' critical thinking skills are included in the medium and high categories (Afadil, 2016). Determination of critical thinking skills from the scores obtained based on indicators is done by matching the scores obtained by students with the level of achievement of the determined critical thinking skills Gronlund (1996) as follows: $85 \% \leq \mathrm{N}$ = very high; $75 \% \leq \mathrm{N}<85 \%=$ high; $60 \% \leq \mathrm{N}<75 \%$ = moderate; $40 \% \leq \mathrm{N}<60 \%$ $=$ low; and $0 \% \leq \mathrm{N}<40 \%$ = very low.

Changes in students' critical thinking skills before and after the application of the SAVI learning model were determined using the $\mathrm{N}$-gain calculation, namely: Normalized gain (N-Gain) = Posttest score - Pretest score/ideal score - pretest score (Hake, 1998).

Table 2. Category normalized gain level

\begin{tabular}{ll}
\hline Limitation & Category \\
\hline $\mathrm{G}>0.7$ & High \\
$0.3 \leq \mathrm{g} \leq 0.7$ & Moderate \\
$\mathrm{g}<0.3$ & Low \\
\hline
\end{tabular}

Table 2 shows the limits and normalized gain categories where if the gain data critical thinking $>0.7$, then the critical thinking gain is included in the high category; if the $\mathrm{N}$-gain calculation results are $0.3 \leq \mathrm{g} \leq 0.7$, then the gain of critical thinking is in the medium category, and if the $\mathrm{N}$-gain calculation is $<0.3$ then the gain of critical thinking is in a low category.

\section{Results and Discussion}

This study aims to describe students' critical thinking skills by applying the SAVI learning model. In accordance with the research design used, a preliminary test was carried out before learning which took place four times on the solubility material and solubility product (Ksp). The last meeting on the lesson was then carried out again the final test.

The stages or syntax of the SAVI model itself consists of four stages, namely the stages of preparation, delivery, training, and performance of the results. The preparation stage is the stage where the researcher arouses students' interest in learning, such as providing motivation and perception and from the beginning involving students to be active in learning.

The delivery stage is the stage where researchers help students find subject matter with various learning resources that involve the students' five senses. This delivery stage students will listen to and listen to the teacher's explanation where the process of delivering this material students not only hear and listen but can also observe the material presented with power point media and video and be directly involved in providing material by way of demonstrations so that it does not only involve the sense of hearing but also involves the sense of sight and touch which can help students to easily understand and be able to think critically.

The training stage is the stage where students will be more active in learning activities, namely researchers will help students to be able to integrate and absorb the knowledge gained by conducting experiments in groups based on the student worksheet provided and not only that students are also directed to discuss because critical thinking can be done by questioning what is seen and heard (Ariyati, 2007). 
The next stage is the stage of displaying the results where the researcher directs students to apply knowledge and expand new knowledge or skills obtained from the given assignment by displaying the results of the discussion. At this stage, students will present the results of the discussions that have been carried out (Alfiyani, 2015).
During the learning process, the observer observes the learning process to see the implementation of the lesson plan using teacher observation sheets and student observation sheets. The results of teacher observations can be seen in Table 3, while the results of student observations can be seen in Table 4 .

Table 3. Results of observation of teacher activities

\begin{tabular}{ccc}
\hline & \multicolumn{2}{c}{ Percentage (\%) } \\
Meeting & Experiment class 1 & Experiment class 2 \\
\hline Meeting 1 & 95.23 & 97.62 \\
Meeting 2 & 95.23 & 95.23 \\
Meeting 3 & 92.85 & 95.23 \\
Meeting 4 & 97.62 & 95.23 \\
\hline Average & 95.23 & 95.82 \\
\hline
\end{tabular}

Table 4. Results of observation of student activities

\begin{tabular}{ccc}
\hline & \multicolumn{2}{c}{ Percentage (\%) } \\
Meeting & Experiment class 1 & Experiment class 2 \\
\hline Meetingn 1 & 92.59 & 98.15 \\
Meeting 2 & 98.15 & 94.44 \\
Meeting 3 & 92.59 & 96.29 \\
Meeting 4 & 96.29 & 96.29 \\
\hline Average & 94.90 & 96.29 \\
\hline
\end{tabular}

Based on the average value of the two experimental classes in Tables 3 and 4, the success rate of the teacher's average action was $95.23 \%$ in the experimental class 1 and $95.82 \%$ in the experimental class 2 , while the average success rate of students' actions in the experimental class 1 and Experiment 2, namely $94.90 \%$ and $96.29 \%$, in this case, the activities of students and teachers are in the very good category, this is in accordance with what is stated in the Depdiknas (2005) that the percentage of activity values is said to be very good if the results are obtained $(91 \% \leq$ Score $\leq 100 \%)$. All learning activities carried out are directed at the research objective, namely students' critical thinking abilities. The ability to think critically isa general term given to the various cognitive skills and intellectual dispositions required to effectively identify, analyze and evaluate arguments. The results of critical thinking skills obtained from the learning outcomes using the SAVI learning model are as follows:

Table 5. Students' critical thinking ability in experiment class 1

\begin{tabular}{ccc}
\hline & \multicolumn{2}{c}{ The number of students } \\
Critical thinking category & Pretest & Posttest \\
\hline Very high & 0 & 0 \\
High & 0 & 6 \\
Moderate & 0 & 10 \\
Low & 0 & 16 \\
Very low & 32 & 0 \\
\hline
\end{tabular}


Table 6. Students critical thinking ability in experiment class 2

\begin{tabular}{|c|c|c|}
\hline \multirow{2}{*}{ Critical thinking category } & \multicolumn{2}{|c|}{ The number of students } \\
\hline & Pretest & Posttest \\
\hline Very high & 0 & 0 \\
\hline High & 0 & 4 \\
\hline Moderate & 0 & 10 \\
\hline Low & 0 & 13 \\
\hline Very low & 27 & 0 \\
\hline
\end{tabular}

Based on Tables 5 and 6 there is an increase in critical thinking skills from very low critical thinking skills, and an increase occurs after the posttest. The number of students with the ability level in the experimental class 1 obtained 16 students with low critical thinking category, 10 students in the moderate category, 6 students in the high category. Experimental class 2 obtained the results of data analysis for the low critical thinking category as many as 13 students, 10 students in the medium category, and 4 students for the high category.

Students' critical thinking skills are measured based on indicators adapted from Facione (2013), namely interpretation, analysis, and inference. The critical thinking ability measured in the subject of solubility and solubility product (Ksp) which is reviewed based on the indicators for experimental class 1 is presented in Table 7 , and experimental class 2 is presented in Table 8 .

Table 7. Percent Data of critical thinking indicators for experiment class 1

\begin{tabular}{ccc}
\hline \multirow{2}{*}{ Indicator } & \multicolumn{2}{c}{$\%$ Per indicator } \\
& pretest & posttest \\
\hline Interpretation & 25.84 & 69.59 \\
Analysis & 11.13 & 61.13 \\
Inference & 2.44 & 53.51 \\
\hline
\end{tabular}

Table 8. Data percent critical thinking indicators for experiment class 2

\begin{tabular}{lcc}
\hline \multirow{2}{*}{ Indicator } & \multicolumn{2}{c}{$\%$ per indicator } \\
& pretest & posttest \\
\hline Interpretation & 23.51 & 79.55 \\
Analysis & 1.38 & 48.61 \\
Inference & 0 & 49.07 \\
\hline
\end{tabular}

The results of the critical thinking ability on the subject of Ksp for the experimental class 1 average score obtained by the interpretation indicator is $69.59 \%$, which is included in the moderate critical thinking ability category, the analysis indicator is $61.13 \%$ is the moderate critical thinking category, and The inference indicator is $53.51 \%$ which is also included in the low critical thinking category while the experimental class 2 is able to obtain an average score for the interpretation indicator of $79.55 \%$ which is the high critical thinking category, the analysis indicator is $48.61 \%$ for the critical thinking category low, and an average inference indicator score of $49.07 \%$ is also included in the low critical thinking category (Afadil, 2016).

The results obtained stated that not all students were able to achieve good critical thinking categories, namely at least the medium and high categories as well as the achievement of each critical thinking indicator; this result was considered satisfactory because students' critical thinking skills were rarely developed in the learning process so that students were not used to critical thinking. Experts claim that not everyone is completely successful in all critical thinking skills because humans sort their lives in such a way that critical thinking is more active in a few cognitive skills, but this does not mean that it is impossible to fully master critical thinking skills if the development of critical thinking continues to be applied in curriculum development (Nur, 2013).

Changes in students' critical thinking skills can be described using $\mathrm{N}$-gain analysis. N-gain analysis is used to determine the general average increase in every aspect of critical thinking skills 
(Kolekci \& Kumlu, 2015; Jamaluddin, 2017). The $\mathrm{N}$-gain analysis is presented in Table 9.

Table 9. The average value of students' pretest, posttest and n-gain critical thinking

\begin{tabular}{ccccc}
\hline Class & Pretest (\%) & Posttest (\%) & N-Gain & Category \\
\hline Ex I & 11.37 & 61.02 & 0.56 & Moderate \\
Ex II & 7.97 & 61.47 & 0.58 & Moderate \\
\hline
\end{tabular}

Based on Table 9, the pretest average value for experimental class I was $11.37 \%$ and experimental class II was $7.97 \%$, while the increase in critical thinking skills of the two classes based on $\mathrm{N}$-gain was included in the moderate category. These results indicate that the critical thinking skills of students after learning the Ksp material using the SAVI learning model have increased, namely 0.56 in the experimental class I or an increase of 56\% from the previous one, while the experimental class II has increased 0.58 or $58 \%$ from the previous one. This result is good enough for students who are not accustomed to being able to think critically in learning activities and students' critical thinking skills will be better if the development of critical thinking continues to be applied in learning activities (Nur, 2013).

\section{Conclusions}

Based on the results of the data analysis carried out, the student's critical thinking ability with the application of the SAVI learning model on the subject of Ksp in the experimental class I for student interpretation and analysis indicators were included in the medium category while the inference indicator was included in the low category while in the experimental class II for analysis indicators and inference is included in the low critical thinking category and the interpretation indicator reaches the high category. In general, the average critical thinking ability of all students for the experimental class I was $61.02 \%$, and for the experimental class 2 was $61.47 \%$, both of which were included in the moderate critical thinking category. Based on these results, students' critical thinking skills with the application of the SAVI model were in a good category.

\section{Acknowledgments}

The author would like to thank Idris Ade, the principal of SMA Negeri 5 Model Palu, and Sugeng Utomo, a chemistry subject teacher at SMA Negeri 5 Model Palu, and all those who helped the author a lot in completing this research.

\section{References}

Afadil, (2016). Model pembelajaran PS-TRILOGI untuk pembelajaran sains di sekolah dan perguruan tinggi. Palu: Untad Press.
Alfiyani, R. 2015. Pengaruh pendekatan pembelajaran SAVI (somatis, auditory, visual, intellectual) dengan metode eksperimen terhadap hasil belajar siswa pada mata pelajaran fisika di $M A N$ Jember. Skripsi Tidak Diterbitkan. Jember: Universitas Jember.

Ariyati, E. (2007). Pembelajaran berbasis praktikum untuk meningkatkan kemampuan berpikir kritis mahasiswa. Jurnal Matematika dan IPA, 1(2), 1-12.

Azizah, N., Atep, S., \& Isrok'atun. (2016). Penerapan pendekatan somatis auditory visual intelektual pada materi sumber energi bunyi untuk meningkatkan hasil belajar siswa. Jurnal Pena Ilmiah, 1(1), 490-500.

Depdiknas. (2005). Evaluasi pembelajaran. Jakarta: Departemen Pendidikan Nasional.

Facione, P. A. (2013). Critical thinking: what it is and why it counts?. Millbrae: California Academic Press.

Fitriyani., Suwatra. I., W \& Kusmariyanti, N. (2015). Pengaruh model SAVI terhadap kemampuan berpikir kritis siswa dalam mata pelajaran IPA kelas V SD. Jurnal PGSD Universitas Pendidikan Ganesha, 3(1), 1-12.3140.

Gronlund, N. E. (1990). Measurement and evaluation in teaching. New York: Macmillan.

Hake, R. R. (1998). Interactive engagement versus traditional methods: a six-thousand-student survey of mechanics test data for introductory physics courses. American Journal of Physics, 66(1). 1-5.

Handhika, J., \& Rofiah, N. (2012). Penggunaan media pembelajaran IM3 ditinjau dari kemampuan berpikir siswa. Jurnal Penelitian Pembelajaran Fisika, 3(1), 109-114.

Iskandar, D., Hamdani, A. R., \& Suhartini, T. (2016). Implementation of model SAVI (somatic, auditory, visualization, intellectual) to increase critical thinking ability in class IV of social science learning on social issues in the local environment. Journal of Education Teaching and Learning, 1(1), 45-50.

Jamaluddin, D. N. (2017). Pengaruh pembelajaran berbasis proyek terhadap kemampuan berpikir kritis dan sikap ilmiah pada materi tumbuhan biji. Jurnal Tadris Biologi, 1(1), 18-41. 
Karim, N. (2015). Kemampuan berpikir kritis pembelajaran matematika dengan menggunakan model jucama di sekolah menengah pertama. Jurnal Pendidikan Matematika, 3(1), 92-104.

Kolekci, G., \& Kumlu, E. (2015). Developing critical thinking skills in english language teaching classes through novels. International Journal of Language Academy, 3(2), 76-90.

Lastyono, J., Slamet, R., \& Marheni. (2012). Upaya meningkatkan kemampuan berpikir kritis siswa melalui pendekatan SAVI pada materi redoks di kelas X SMA Negeri 2 Jakarta. Jurnal Riset Pendidikan Kimia, 2(1), 91-98.

Nur, M., Nasution., \& Suryanti, J. (2013). Berpikir kritis. Surabaya: Universitas Negeri Surabaya.

Nurkholifah, S., Toheri \& Winarso, W. (2018). Hubungan antara self confidence dengan kemampuan berpikir kritis siswa dalam pembelajaran matematika. Edumatica: Jurnal Pendidikan Matematika, 08(01), 58-66.

Rachman, F. A., Riska, A., \& Effendi, N. (2017). Pengembangan LKPD berbasis berpikir kritis materi kelarutan dan hasil kali kelarutan pada materi pelajaran kimia di SMA. Alkimia: Jurnal Ilmu Kimia dan Terapan, 1(1), 16-25.
Setiyono, F. P. (2011). Pengembangan perangkat pembelajaran kimia kelarutan dan hasil kali kelarutan (Ksp) dengan pendekatan SETS untuk meningkatkan kemampuan berpikir kritis dan kreatif siswa. Jurnal Pengembangan Perangkat, 1(2), 149-158.

Sukmadinata, N. S. (2012). Metode penelitian pendidikan. Bandung: PT Remaja Rosdakarya.

Sumawardani, W., \& Chairil, F. P. (2013). Efektivitas model pembelajaran SAVI dalam pembelajaran matematika untuk mengembangkan karakter mandiri siswa. Jurnal Pendidikan Matematika, 1(1). 82-89.

Susilowati, S., \& Murni, R. (2018). Keefektifan perangkat pembelajaran berbasis inquiry lesson untuk meningkatkan keterampilan berpikir kritis siswa. Jurnal Penelitian dan Evaluasi Pendidikan, 22(1), 49-60.

Suyadi. (2013). Strategi pembelajaran pendidikan karakter. Yogyakarta: Remaja Rosdakarya.

Wiyani, N. A. (2012). Desain pembelajaran pendidikan. Yogyakarta: Ar-ruzz Media.

Winarno, Patwary,. A. A., Yasid, A., Marzuki, R., Rini, S. E., \& Alimah, S. (2009). Teknik evaluasi pembelajaran. Yogyakarta: Genius Prima Media. 